\title{
ANAESTHETIC CONSIDERATIONS IN CAESAREAN SECTION FOR QUADRUPLETS
}

\author{
John B. Craft, Gershon Levinson, And Sol M. Shnider
}

\begin{abstract}
ANAESTHETIC CONSIDERATIONS for the vaginal delivery of quadruplets have been discussed recently. 'Epidural analgesia for the patient delivering quadruplets by caesarean section has hitherto not been described. A case report and the rationale for the anaesthetic technique used is presented.
\end{abstract}

\section{Case History}

The patient was a 30-year-old black female, gravida 2 para 1, who had taken clomiphene citrate five months before this pregnancy. A sonogram obtained at 35 weeks' gestation demonstrated four foetuses and a large single anterior low placenta. The patient was admitted to the hospital for bed rest to prevent premature labour. Since the presenting foetus was in a transverse lie, an elective caesarean section at term was planned. The patient strongly preferred regional anaesthesia and since there were no symptoms of aorto-caval compression syndrome when she assumed the supine position, a decision was made to use epidural analgesia. The patient was typed and cross-matched for four units of blood in anticipation of possible uterine atony and haemorrhage.

At 38 weeks the patient weighed $83.2 \mathrm{~kg}$ (gestational gain of $29.5 \mathrm{~kg}$ ), was $155 \mathrm{~cm}$ tall, and had a blood pressure of $110 / 70 \mathrm{~mm} \mathrm{Hg}$. Serum electrolytes, blood urea nitrogen (BUN), uric acid, creatinine, SGOT, LDH, alkaline phosphatase and serum proteins were normal and the haematocrit was 31.4 per cent. An amniocentesis was undertaken to determine the lecithin/sphingomyelin ratio, but blood was obtained and no

John B. Craft, M.D., Associate Professor of Anaesthesia, Obstetrics and Gynaecology, George Washington University, Washington D.C., 20037.

Gershon Levinson, M.D., Assistant Professor of Anaesthesia, Obstetrics, Gynaecology and Reproductive Sciences, University of California, San Francisco, California, 94143.

Sol M. Shnider, M.D., Professor of Anaesthesia, Obstetrics, Gynaecology and Reproductive Sciences, University of California, San Francisco, California, 94143.

Reprint requests to John B. Craft, M.D., George Washington University Hospital, 901 - 23rd Street, $\mathrm{NW}$, Washington D.C., 20037.

Canad, Anaesth. Soc. J., vol. 25, no. 3, May 1978 further attempt made. On the day of operation, after administration of $30 \mathrm{ml}$ oral antacid, $800 \mathrm{ml}$ of balanced salt solution was infused through two 16-gauge intravenous catheters and the patient was placed in the left lateral position. A lumbar epidural block was performed with ease using a midline approach at $\mathrm{L}_{4}-\mathrm{L}_{5}$ and $15 \mathrm{ml}$ of 3 percent chloroprocaine were injected, producing a level of analgesia to $T_{4}$. Despite a left lateral tilt, there was an initial hypotensive episode to $110 / 70 \mathrm{~mm}$ $\mathrm{Hg}$. Blood pressure was restored immediately to $120 / 60 \mathrm{~mm} \mathrm{Hg}$ with further left uterine displacement, rapid infusion of an additional $1000 \mathrm{ml}$ of balanced salt solution, oxygen administration and small intravenous doses of ephedrine to a total dose of $50 \mathrm{mg}$. When the uterus was incised, the placenta was inadvertently lacerated and the four foetuses were delivered rapidly (Table I).

TABLE I

\begin{tabular}{|c|c|c|c|c|}
\hline Neonate & $\mathbf{A}$ & $\mathbf{B}$ & $\mathrm{C}$ & $\mathbf{D}$ \\
\hline Sex & $\mathbf{F}$ & $\mathbf{F}$ & $\mathbf{M}$ & $\mathbf{F}$ \\
\hline Time of delivery & $8: 47$ & $8: 49$ & $8: 49$ & $8: 50$ \\
\hline Crying time & \multicolumn{4}{|c|}{ - - - - immediate ..... } \\
\hline \multicolumn{5}{|l|}{ Apgar score } \\
\hline One minute & 7 & $5 *$ & 8 & 6 \\
\hline Five minutes & 8 & 8 & 8 & 8 \\
\hline Weight (kg) & 2.1 & 2.3 & 2.5 & 1.4 \\
\hline Weight of placenta $(\mathrm{kg})$ & \multicolumn{4}{|c|}{$\ldots-3.5 \ldots \ldots$} \\
\hline
\end{tabular}

*Due to vigorous pharyngeal suctioning.

Uterine atony was treated by infusion of 100 units of pitocin in a litre of intravenous solution. The blood loss, estimated to be $1500 \mathrm{ml}$, was treated by infusion of $1000 \mathrm{ml}$ of whole blood. Maternal blood pressure and heart rate were unchanged. The neonates were placed in 30 per cent oxygen immed iately, but this was discontinued within 30 minutes. All the neonates were discharged with their mother in seven days excepting baby $D$, who was kept in hospital for four weeks until her weight was $2.25 \mathrm{~kg}$.

\section{Anaesthetic Consideration}

In selecting the method and anaesthetic agents to be used when providing anaesthesia for caesarean delivery of quadruplets, consideration must be given to each of the following factors: 
(a) The parturient is at great risk for hypotension. Most obstetrical patients have some degree of aorto-caval compression by the gravid uterus. One might expect this effect to be exaggerated with multiple gestations, particularly at term. ${ }^{2}$ If subarachnoid or epidural spinal block is used there is a concomitant sympathetic block with vasodilation and pooling of blood in the lower extremities. The combination of these factors may lead to decrease in venous return and cardiac output and severe hypotension, with a reduction of uterine blood flow. ${ }^{3}$ Left uterine displacement, rapid infusion of balanced salt solution and small doses of ephedrine will significantly reduce the incidence of hypotension. ${ }^{4,5}$ In addition to these factors, it has been reported that post-partum haemorthage secondary to uterine atony is two to three times more common with multiple gestations than it is with a single foetus. ${ }^{6}$ Patients with a sympathetic blockade from a lumbar epidural block will not vasoconstrict in response to blood loss as well as patients under general anaesthesia and thus there is a greater risk of hypotension.

(b) The parturient with quadruplets may be at risk for marked respiratory distress when in the supine position because of the grossly enlarged uterus. Bevan, et al. ${ }^{7}$ demonstrated that in the supine position, with a single foetus, one-third of parturients develop airway closure during normal tidal volume, presumably because of upward displacement of the diaphragm. Multiple gestations with an even larger uterus would be expected to accentuate this tendency toward hypoxaemia. However, Templeton, et al. ${ }^{8}$ demonstrated that patients with a single gestation at term, breathing air in the semirecumbent position with a left lateral tilt had a $\mathrm{Pa}_{2}$ greater than 100 torr, and no change in $\mathrm{PA}_{\mathrm{O}_{2}}-\mathrm{Pa}_{\mathrm{O}_{2}}, \mathrm{VD} / \mathrm{VT}$ or percentage of shunt. Nonetheless, it would seem prudent to give supplementary oxygen to patients having epidural anaesthesia for caesarean section. General anaesthesia with positive pressure ventilation would also minimize airway closure with atelectasis and hypoxaemia.

(c) The parturient is at increased risk for aspiration of gastric content. At term, there is a delay in gastric emptying because of uterine displacement of the pylorus and because progesterone decreases gastric motility. By displacing the stomach the enlarged uterus also changes the angle between the stomach and oesophagus, tending to render the gastro-oesophageal sphincter incompetent. In addition, the hormone gastrin produced by the placenta is greatly increased during gestation, resulting in production of acidic gastric juice. ${ }^{9}$ The presence of multiple gestations with grossly enlarged uterus and placenta should accentuate these effects. These patients especially should be considered at risk for acid aspiration pneumonitis and should be treated with oral antacids ${ }^{10}$ before induction of anaesthesia.

(d) The foetuses are usually premature and often manifest intrauterine retardation of growth secondary to reduced utero-placental blood flow. " Foetal size appears to be independent of the number of foetuses until the 28th week of gestation, from which time there is a progressive lag in weight behind singletons. This lag in weight is more pronounced with increasing numbers of foetuses. Mortality among multiple embryos increases as the birth weight decreases ${ }^{12}$ and is reported to be $509 / 1000$ for quadruplets. ${ }^{13}$ Prematurity may lead to an increased susceptibility to the depressant effects of general anaesthetics and may decrease the ability of the neonate to adapt to extrauterine life. ${ }^{14}$

(e) Each successive foetus has a less efficient placental unit at birth than the one born preceding it. ${ }^{15}$ This is the result of three factors: (1) partial separation of the placenta, (2) contraction of uterine muscle around the vessels, (3) obstruction of the umbilical cord. Utero-placental insufficiency leads to increasing foetal hypoxaemia, hypercarbia and metabolic acidosis and a further sensitivity to any depressant medication or anaesthetic that may have been given. If a general anaesthetic is given for delivery, each successive foetus will obviously receive more anaesthetic and may have more central nervous system depression than those preceding. ${ }^{15}$ If a major regional anaesthetic is given, maternal hypotension or reduced uterine blood flow will have greater consequences because of the already compromised utero-placental blood flow. Use of an agent such as chloroprocaine, which has a plasma half-life of 21 seconds in the mother and 43 seconds in the foetus, ${ }^{16}$ will avoid any direct depressant effect of the local analgesic on the foetus.

(f) There must be adequate obstetrical, anaesthetic and paediatric personnel to provide optimum care for both mother and neonates, whatever anaesthetic technique is used. This implies that each neonate has its own resuscitation team. In addition, since significant maternal blood loss may occur during the intra-partum and post-partum periods, a minimum of four units of blood should be available in the delivery suite.

Attention to detail and anticipation of the prob- 
lems to be encountered should lead to a successful conclusion with either regional or general anaesthesia. Regional anaesthesia was selected in our patient primarily because of her strong desire to be awake for the delivery. Following initiation of the block she became mildly hypotensive but rapidly responded to the usual therapeutic maneuvers. Uterine atony occurred and was promptly treated with a larger than usual dose of pitocin. Despite an estimated $1500 \mathrm{ml}$ blood loss in our sympathectomized patient, the rapid infusion of two units of whole blood prevented the occurrence of hypotension. All the neonates did well and had Apgar scores of 8 at five minutes.

Keeping the anaesthetic considerations in mind, it is obvious that there is no ideal anaesthetic technique for elective caesarean section for quadruplets. Maternal considerations of hypotention, respiratory embarrassment and aspiration of gastric content and foetal considerations of prematurity and impaired placental function are formidable obstacles to be overcome.

\section{SUMMARY}

A case of a caesarean delivery with epidural analgesia of a term parturient with quadruplets is presented. Maternal considerations of hypotension, respiratory embarrassment and aspiration of gastric content and foetal considerations of prematurity and impaired placental function are discussed relative to the use of general anaesthesia or epidural analgesia.

\section{RÉSUMÉ}

On a publié récemment ${ }^{1}$ une discussion des considérations anesthésiques pour les accouchements de quadruplets par voie vaginale. Nous rapportons ici notre expérience d'un cas de césarienne sous anesthésie péridurale pour un accouchement de quadruplets. Dans une telle situation, il faut considérer les points suivants:

(a) Les risques d'hypotension sont grands, les effets de compression aorto-cave étant augmentés par un volume utérin considérable. Sil'on ajoute la vasodilatation avec "pooling" sanguin secondaire au bloc sympathique produit par la péridurale, on peut observer une chute du débit cardiaque avec hypotension et diminution du dẻbit sanguin utérin. ${ }^{3}$ De plus, l'on a rapporté qque l'incidence d'hémorragie post-partum par atonie utérine est deux à trois fois plus fréquente dans les grossesses multiples que dans les accouchements ordinaires. ${ }^{6}$

(b) Le volume utérin très élevé implique un plus grand risque de détresse respiratoire chez la mère.

(c) La possibilité de régurgitation et d'aspiration de liquide gastrique est également augmentée. Aussi devrait-on administrer des antacides per os aux patientes avant l'induction.

(d) Les bébés naissent en général de façon prématurée et souffrent fréquemment d'un retard de croissance intra-utérine à cause d'un débit sanguin placentaire diminué. Leur état de prématurés les rend plus susceptibles à la dépression par les anesthésiques généraux et diminue également leur capacité d'adaptation à la vie extra-utérine.

(e) Chacun des fotus restant aura proportionnellement moins de tissu placentaire fonctionnel que ceux nés avant lui. Si l'on utilise une anesthésie générale, chacun des foetus successifs recevra également plus d'agent anesthésique que ceux qui sont déjà nés. Avec une anesthésie régionale, un épisode d'hypotension maternel aura des conséquences croissantes sur chacun des fœetus successifs.

(f) Le personnel obstétrical, anesthésique et pédiatrique doit être compétent et suffisant pour fournir des soins optima à la mère et aux bébés. Chacun des nouveau-nés devrait avoir sa propre équipe de réanimateurs.

\section{REFERENCES}

1. Agouleish, E. Caudal analgesia for quadruplet delivery. Anesth. and Analg. 55:61-66 (1976).

2. Kim, Y., Chandro. P.. \& Marx, G. Successful management of severe aorto-caval compression in twin pregnancy. Obstet, and Gynecol. 46: 362-364 (1975).

3. Scotr, D.B. Parturition and perinatology. Clinical anesthesia series, 1 st ed, Philadelphia. F.A. Davis, p. 38 (1974).

4. Eckstein, K. \& Marx, G. Aorto-caval compression and uterine displacement. Anesthesiology 40: 92-96 (1974).

5. Wollman, S.B. \& Marx, G. Prevention of hypotension of spinal anesthesia in parturients by acute hydration. Anesthesiology 29: $374-380$ (1968).

6. Little, W.A. \& Friedman, E.A. The twin delivery factors influencing second twin mortality - a review. Obstet. and Gynecol. Survey 13: 611 (1958).

7. Bevan, D.R., holdcraft, A., Loh, L., MacGregor, W.G., O'Sullivan, J.C., \& Sykes, M.K. Closing volume and pregnancy. Br. Med. J. $l: 13$ (1974). 
8. Templeton, A. \& Kelman, G. Maternal gas, physiologic shunt and $\mathrm{VD} / \mathrm{VT}$ in normal pregnancy. Br. J. Anaesth. 48: 100 $\mathrm{i}-1004$ (1976).

9. AtTia, R.R., Amin, M.E., \& Fischer, J.E. Gastrin: placental, maternal and plasma cord levels its possible role in maternal residual gastric acidity. Abstracts of Scientific Papers. Annual meeting, American Society of Anesthesiologists, pp. $547-548(1976)$.

10. Roberts, R. \& ShirLey, M. Reducing the risk of acid aspiration during caesarean section. Anesth. and Analg. 53: 859-868 (1974).

II. McFee, J.G., Lord, E., JefFrey, R., O'Meara, O. JOSEPHER, H. BuTTERFIELD, J.. \& Thompson, H. Multiple gestations of high fetal number. Obstet. and Gynecol. 44: 99-106 (1974).

12. Daniels, J.C. \& Hehre, F.W. Anesthetic consid- erations for complicated obstetrics. Anesth. and Analg. 46: 527-539 (1967).

13. Record, R.G., Gibson, J.R., \& Mckeown, T. Foetal and infant mortality in multiple pregnancy. J. Obstet. Gynaec. Brit. Emp. 59:471 (1952).

14. BonICA, J.J. Principles and practice of obstetric anaesthesia and analgesia. 1st ed., Philadelphia, F.A. Davis, p. 1270(1967)

15. BonicA, J.J. Principles and practice of obstetric anesthesia and analgesia: Ist ed., Philadelphia, F.A. Davis, p. 130 । (1967)

16. Finster, M. Perel, J.M., Hinsvark, O.N., \& O'BR1EN, J.E. Reassessment of the metabolism of 2-chloroprocaine hydrochloride (Nesacaine ${ }^{40}$ ). Abstracts of Scientific Papers. Annual Meeting, American Society of Anesthesiologists, pp. 29-30 (1973). 